\title{
M. Kaneko: A Study on the Human Muscle Power with Inertia Ergometer
}

\section{慣性エルゴメーターによる 人体・筋パワーの測定}

米京人学，金子公䒴

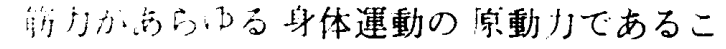

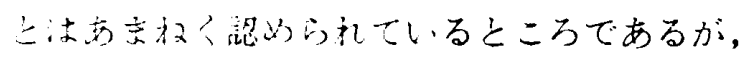

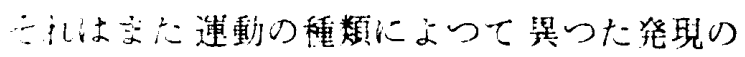

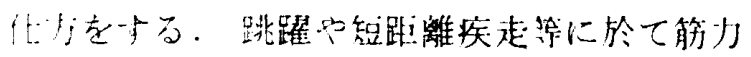

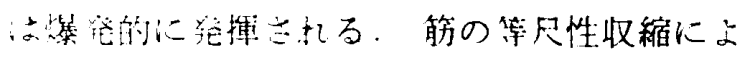

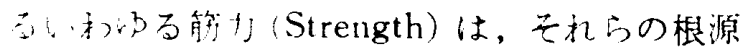

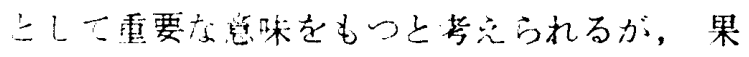

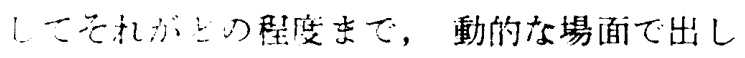

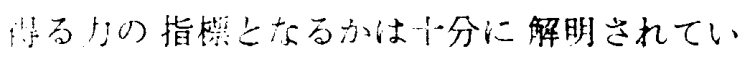

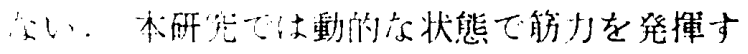
万能力在機諓的任事 (mechanical work) で

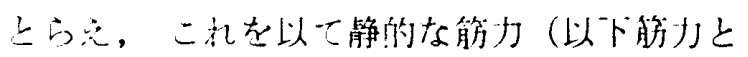
いう）との网倸を検礼しょうとしたものであ る。梴来こらした動的条件下で発揮される筋 カの多くは，ハワーないし瞬発力と称して測 定されている。白代表的な垂值跳びは， McCloy 11) をはじめとする幾多の研究者によ つて, 特汇瞬烧的に筋力を発揮する棁技種目 との間に滈い相関が認好られている。しかし ながら考案者の Sargent, D.A. (1921) 自身 が垂直跳びをバワー・デストとしながらその 指標に $\mathrm{SW} / \mathrm{H}$ ( $\mathrm{S}$; 跳躍高の合社, $\mathrm{W}$; 体重 $\mathrm{H}$; 身長) t採用L，Englehaldt J.L.2) (1924) が $\mathrm{S} V$ w/H を最も適当な index とした梯に， 必㝍しも力学的に定義されるパワー（仕事率） を測つてはいない，近年 Gray, R.K.4) らは，
重直跳びの成䋨をハワー（仕事率）で表わす べきだとして簡便に仕事率を算出する方法を 提案したが，彼らはその後の研究ら)で，単に 仕事堛で表わしても十分にその目的を達し得 る事を認めている。この樣化体育・スポーツ の分野でハッーと称しているものは必ずしも dimension を仕事率で表わしてはいないが， 短時間に大なる仕事をすることによつてその 成績を上代得るといら点に，ハャー・テテスト といわれる所以があると解される。本研究に 於汁る仕事量は，規定の距離内て慣性質量比 少を加兄，如何に速い速度を起し得るかによ つて決定されるものであつて，仕事率とも当 然密接な関係を吅（四4参照）。慣性エルコ メーターは A.V. Hill 6) (1922) に始まり, Lupton, H. 10) (1923), Hannsen, T.E. ?) (1923)，奥山13) (1932) らが，い羊れす人筫 の最大仕事と筋收緶速度の関係を検する為保 使用した，本器によれば，1）被検者に共通な 負荷（慣性質量）のもとで力を発揮させ，2） 動棆の慣性モーメント（恒数）之角速度から 容易に仕事量が得门れる。 3 ) 半径の異る滑車 にワイヤーをかける事により容易に角荷を変 光る事が出来，4）測定姿勢等の条件規定がし 易く，5）運動を単純化して測定出来るので， ほほ同一管群による仕事量と筋力を対比して 
検討するのに好都合である，6）又比較的短時 間に多くの被検者を測定する事が河能である， 等の利点をるつ．本研究はこの慣性エルゴメ 一ターを用いて多くの被検者の仕事量を測定 し，筋力との関係に於てこれを考察しようと したものである。

\section{研究方法}

\section{1. 測定装置}

仕事量測定に 使用した慣性エルゴメーター は困1の如きものである。即ち段滑車状をし

图 1 慣性エルゴィーターの動輸部

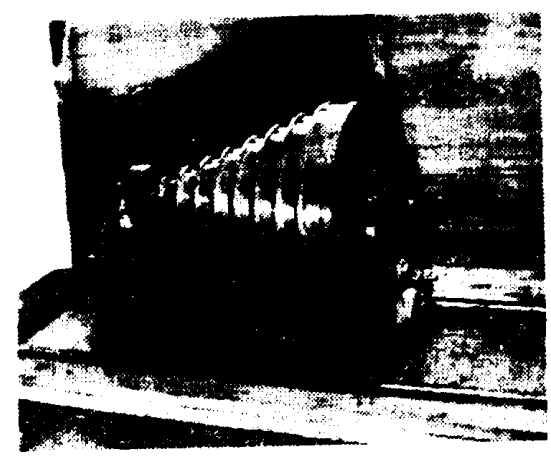

た鉄製の動輸（fly whee）の軸が，両端をボ ールベアリングで支持され極めて回転自由な 状態におかれている.動輸の全体積 $6205.8 \mathrm{~cm}^{3}$, 重量は $48.6 \times 10^{3} \mathrm{~g}$ である。動输のるつ慣性 モーメントの決定に当つては，先ず各滑車 （軸及び辺绿部を含む）の慣性モーメント

$$
\mathrm{I}^{\prime}=\int_{0}^{2 \pi} \int_{0}^{\mathrm{R}}(\rho \cdot \mathrm{r} \cdot \mathrm{d} \theta \mathrm{dr}) \mathrm{r}^{2}
$$

の合計によつて算出する一方，次の様な実験 によりこれを確かめた。即ちワイヤーの一端 を動陯に巻き他端に錘りを吊し，動輪に巻い たワイヤーの距離と等しい高さから落下させ た。この時錯りの位置エネルギーの変化分は 鍾りと動輪の得た運動エネルギーに等しいか $5 \mathrm{mgh}=1 / 2 \mathrm{mv}^{2}+1 / 2 \mathrm{I} \omega^{2}$ （I；動輪の慣性乇 一メント， $\omega$ ；角速度）である。但し錘りの 最高速度（v）はワイヤーが動輪を離れるとき の滑車周上の接線速度に等 しいと考え， $\mathrm{v}=$ ro（r；滑車の半径）とし，慣性モーメント

$$
\mathrm{I}=\mathrm{mr}^{2}-2 \mathrm{mgh} / \omega^{2}
$$

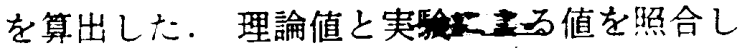
誤差を検討したのら，動輪の慣性モーハント (I) を

$$
\mathrm{I}=27.6 \times 10^{7} \mathrm{gcm}^{2}
$$

と決定した。尚, 負荷は半径の大なる程小さ くなる，即ら中心より半径 $\mathrm{r}$ の部分で接線方 向に力 (F) を加えると，出運動量の定理よ i) $\mathrm{Fr}=\mathrm{Id} \boldsymbol{\mathrm { d }} / \mathrm{dt}$ となり，これを $\mathrm{F}=\mathrm{I} / \mathrm{r}^{2} \cdot \mathrm{rd} \boldsymbol{\omega}$ /dt と書きかえれば $\mathrm{r} \cdot \mathrm{d} \omega / \mathrm{dt}$ はとりもなおさ ずその半径 ( $\mathrm{r}$ ) 部の加速度である。従つて $\mathrm{l} / \mathrm{r}^{2}$ は半径 ( $\mathrm{r}$ ) 部に於ける等価值量 (Equi-

\begin{tabular}{|c|c|c|c|c|c|c|c|c|}
\hline $\begin{array}{c}\text { 滑 } \\
\text { No. 車 }\end{array}$ & 1 & 2 & 3 & 4 & 5 & 6 & 7 & 8 \\
\hline $\begin{array}{c}\text { 半 } \\
\mathrm{cm}\end{array}$ & 2.0 & 3.5 & 5.0 & 6.5 & 8.0 & 9.5 & 11.0 & 12.5 \\
\hline $\begin{array}{c}\text { 等俩㜔量 } \\
\mathrm{kg}\end{array}$ & 685.0 & 223.0 & 109.6 & 64.8 & 42.8 & 30.3 & 22.6 & 17.5 \\
\hline
\end{tabular}
valent Mass）を意味する，各半径の滑車に於 ける等価留量は表1に示した通りである。

角速度の記録は動輪の回転蟿に電気接点を 装着し，1/2 回転に 1 個のパルスダ 記録出来 るようにした。これは最初 $1 / 36$ 回転に 1 個の パルスで検討した結果，最高速度は数秒間持 続し，1/2回転1個のバルスで充分使用に耐 える事がわかつたからである．記録は力の作 用の終つた時点から 1 秒間のパルスを数え， 副尺を用いて $1 / 10 \pi \mathrm{radian} / \mathrm{sec}$ まで読みと つた．尚主として論議の中でとり上げた張力 困の湘定器具は，新與通信 K.K. 製の張力計 (strain meter) LC-100K の外枠をとりはず して用いたものである。また筋電図は全て表 面電極によつて導出し，他の記録と共にイン ク書きオッシログラフ IR-201 型（三栄湖器 製）に記録した。

\section{2. 测定智勢及び方法}

対象とした運的は绝屈曲（时関節 屈曲）及

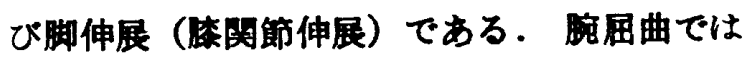
椅座姿勢で上腕を体测方水平にして台上にお 
き，前腕を垂直に立て腕屈曲用ハンドルを握 る.ハンドルの把手部には張力計を介して率引 ワイヤーがとり付けられて怙り，ワイナーの 他端の部形部は, 約 $1.5 \mathrm{~cm}$ 被検者の側方に噰 れた動陯上の釘にかけ胡；规定距離 $(25 \mathrm{~cm})$ 滑車周上に巻かれる。被㭘者は合因と共に力 一杯瞬発的に腕を屈曲して動輪を回転させる （図 2-1）。

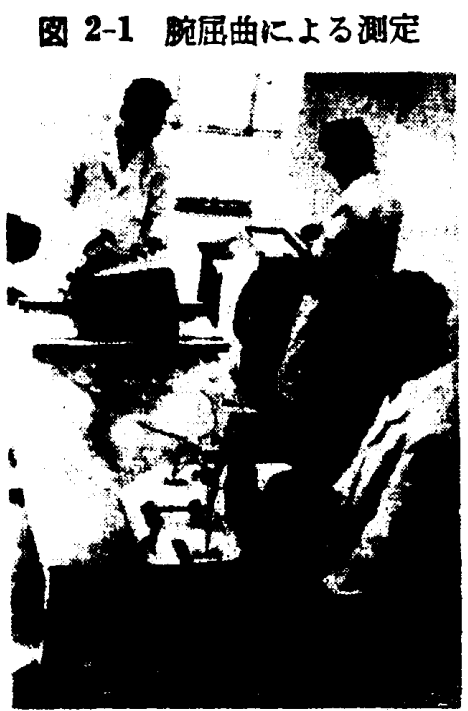

唧伸眼の場合，被検者は高き䄪 $1.2 \mathrm{~m}$ の椅 子に坐寸。 $2 \mathrm{~m}$ 後方の動輪にはワイヤーの一 湍が $30 \mathrm{~cm}$ （陸上競技選手は $40 \mathrm{~cm}$ ）巻か水，

图 2-2 脚伸展による浿定

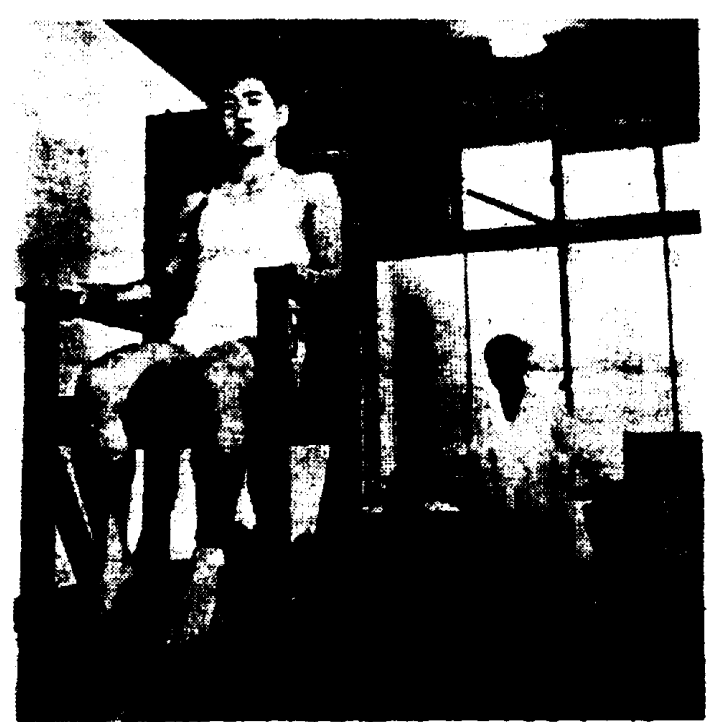

その他端は張力計を介して足頚部のベルトに とりつけられる．被模者は下眼を重直に下げ た姿勢から力一杯腅関節を伸展し，ワイヤー を較引する（因 2-2）。

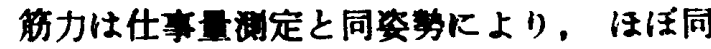
一箭群による静的な筋力を背筫力計によつて 测定した。

被㭘者は小・中・高・大学生及び陸上镜技 選手総数 1109 名である。

\section{桔果及び周前}

\section{1. 仕事量と運動速度}

最大努力て瞬発的に力を発揮しても，負荷 の大きさによりなし得る仕事量は変り，角荷 の增大と共に仕事量は增加する．又仕事之運 動速速度の成保は，Fenn, W.O.3) 等が見出し た樣に指数函数となる。因3は陸上競技選手 (34名）の脚伸展による平㚬值を plot したも のである (Velocity は平均速度の平均)。主 た Wilkie, D.R.14) が指摘している樣に，仕 事一速度の指数 函数関係は個人によつて倸数 が若于変る。

图 3 各負荷に於け万仕事量と速度の関俰 （但し速度は平均率引追度の平均）

Relationship of Work and Velocity

Track a Fierd Athiels (34)

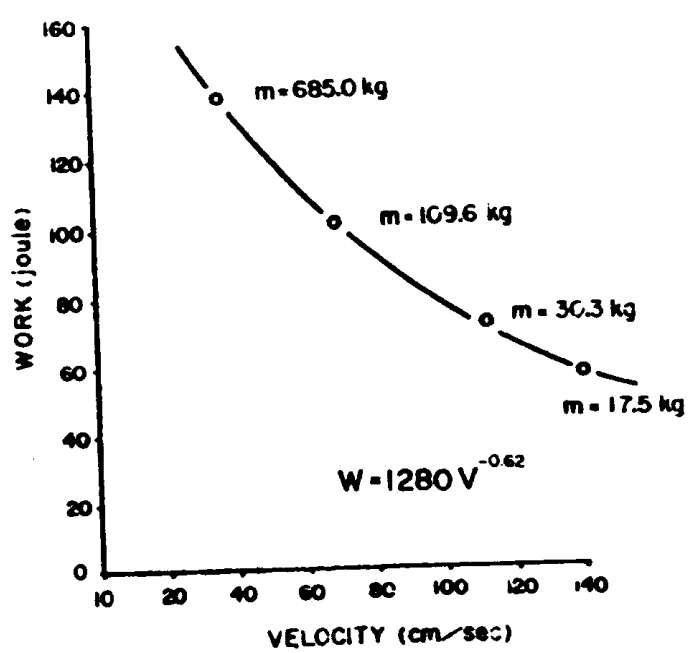


2. 仕事量と仕事率

本研究では規定距離内で慣性質至に対して 力を加皃，如何に速く動陯を回転させ得たか によつて決定される仕事量（work）で表わし たが，張力計をワイヤーにとりりうこjの作 用時間を知り，仕事率（power）を算出して 仕事量との間係をみると，同一負荷に於ける 両者の値は互いに密接な関係にある。即ち仕 事量の大なる者は仕事事す大となる。图4は その一例を示したるのであるが，各負荷，各 被桧者群について，仕事量と仕事寀の相関を みると，いずれる相関釈数 $\mathrm{r}=0.94$ 以上とな り，これは $0.1 \%$ 水準で有意である．従つて少 なくとも本研究の様な条件下では，仕事量で 表わしてもそれは仕事率としての能力をる閣 接的に表わしていると零えよう。

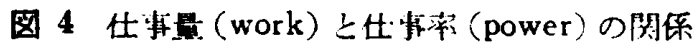
Work and Power (Leg)

(high school boys)

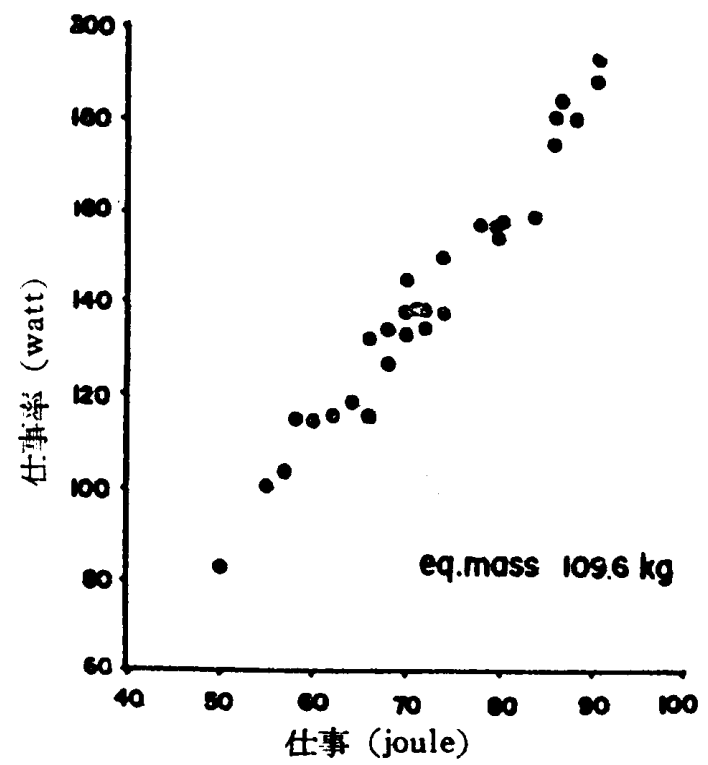

3. 仕事量と筋力の関係

静的な状態での力, 即ちいわゆる筋力に優 れたものが，果して洏的な条件下でる相応し た力を発揮し，仕事量に於ても良い成嘖を上 げ得るかどらかこれが本研究の主通である。 2 種の負荷のもとで脚伸展により测定した高
校及び大学生の結果から，仕事量と筋力の関 係を大学生の場合に 例をとつて困示したもの が図 5,6である。この被検者群の場合は華引 距離が $30 \mathrm{~cm}$ と規定され，最初から回転自由 な状態におがれ動陯を，全く随意的に最大 努力で率引したものである．表 3 はこの時の 平均率引速度の平均值である，四から筋力大 なる者程仕事量す大きい事が睤察されるが，

图 5 仕事量と筋力（大学生男子）

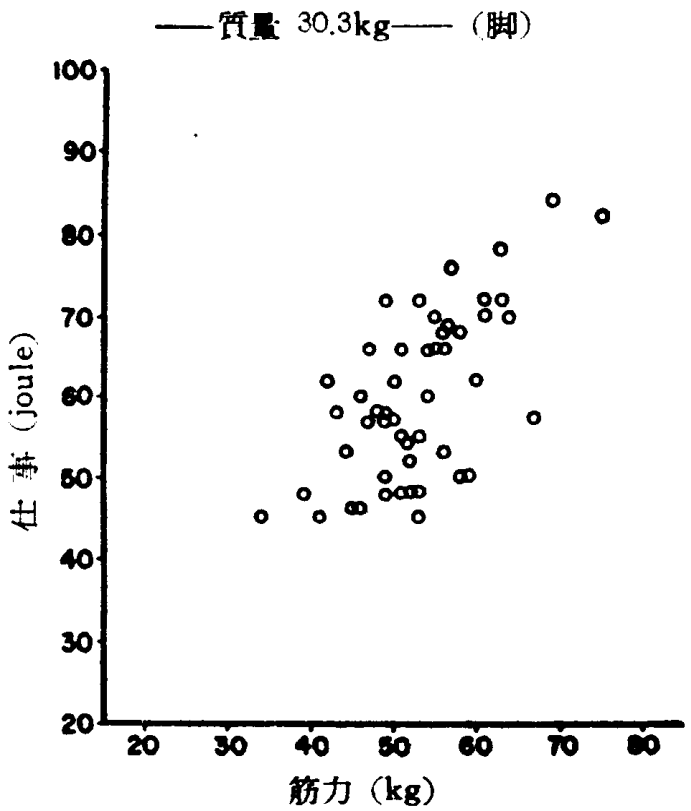

图 6 仕事量と筋力（大学生男子）

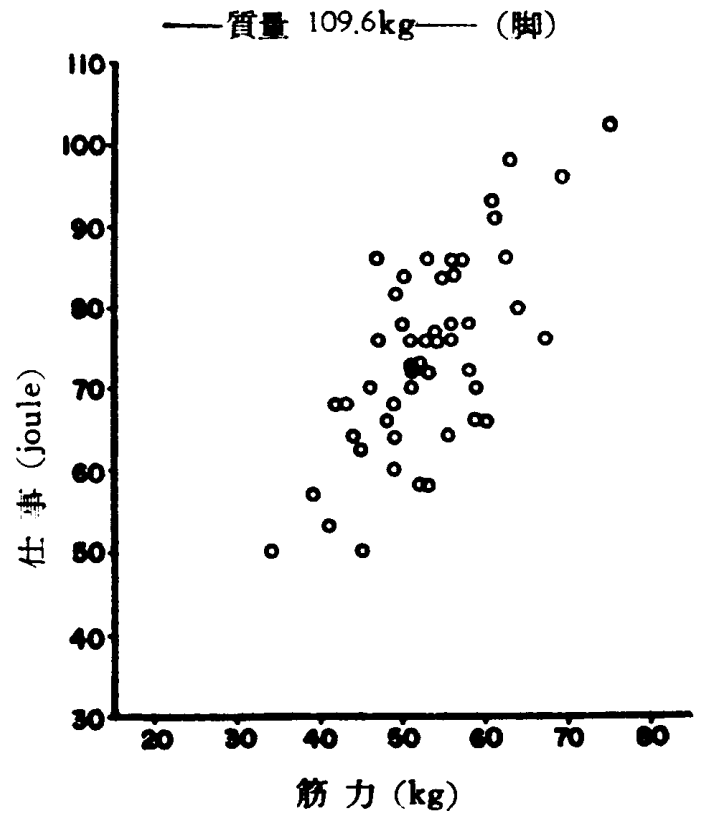


衰 2 仕事量と筋力との相夙

(脚伸展) ( $30 \mathrm{cmpull}$ )

\begin{tabular}{c|c|c|c}
\hline 等価筫至 & 大 学 $(n=50)$ & 高 校 $(n=30)$ \\
\hline $109.6 \mathrm{~kg}$ & $\mathrm{r}=0.699 \mathrm{t}=6.77^{* * *}$ & $\mathrm{r}=0.831 \mathrm{t}=2.49 * * *$ \\
$30.3 "$ & $\mathrm{r}=0.636 \mathrm{t}=5.71 * *$ & $\mathrm{r}=0.724 \quad \mathrm{t}=2.55 * *$ \\
\hline
\end{tabular}

衰 3 平的較引速度の平的 $(\mathrm{cm} / \mathrm{sec})$

\begin{tabular}{c|c|cc}
\hline 等価質豆 & 大 学 $(\mathrm{n}=50)$ & 高 & 校 $(\mathrm{n}=30)$ \\
\hline $109.6 \mathrm{~kg}$ & $58.8 \mathrm{~cm} / \mathrm{sec}$ & $55.5 \mathrm{~cm} / \mathrm{sec}$ \\
$30.3 "$ & $90.9 \mathrm{~cm} / \mathrm{sec}$ & $89.5 \mathrm{~cm} / \mathrm{sec}$ \\
\hline
\end{tabular}

その相関係数を求めてみれば表 2 となり，両 者䦭の相関はい苟机の場合も $1 \%$ 水準で有意 である。鲗荷の大なる場合程师加え易くな 门，力の集積（力積）も增寸事を考虑すれば， 绝茌の大なる場合により相関係数が大となる 事电理解出来る・では筋力の相異がどの様な比

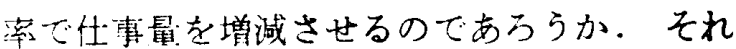
は回帰によつて知る事が出来る。仕事量の筋

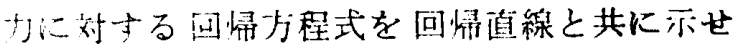
汇図9,10 となる。念の為に回㷌係数の有意性 を稌刢したとこういずれも1\%水準で有意と なり仕事量の筋力に対する回帰の存在するこ とは確かである(表4)。ここで方法的に若干論

图 7 筋力に対する仕事量の回帰 （高校生男子）

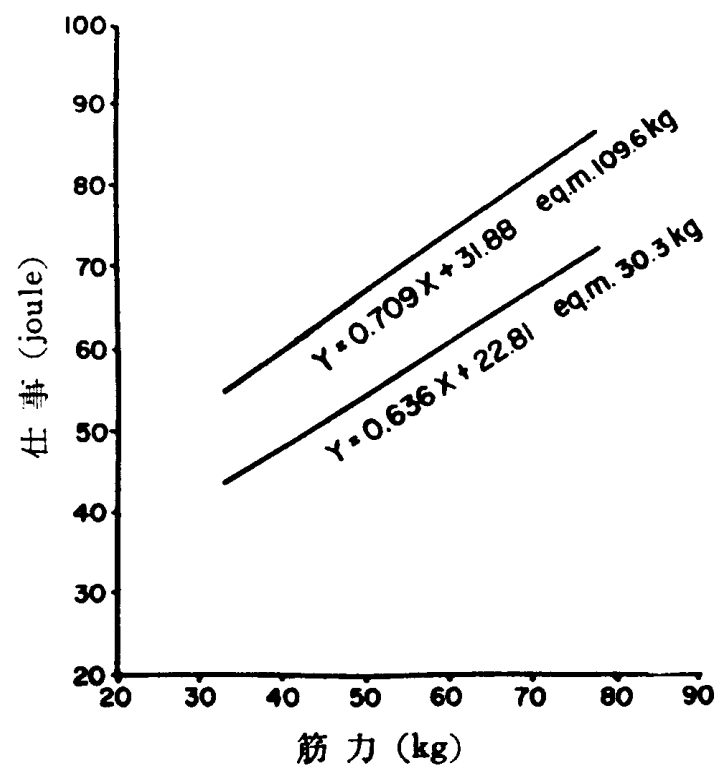

图 8 筋力に対する仕事畫の回琶 （大学生男子）

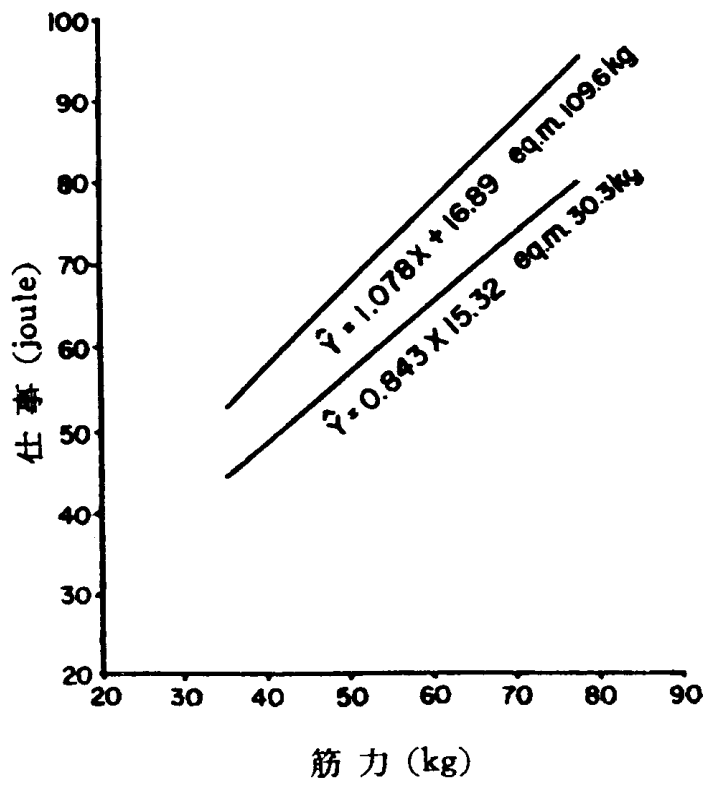

表 4 䈘力に対する仕事量の回帰俰数

\begin{tabular}{|c|c|c|c|c|c|}
\hline & 第価質量 & $\mathbf{N}$ & 回帰係数 & $t$ & 有意水潐 \\
\hline 大 & $109.6 \mathrm{~kg}$ & 50 & $b=1.078$ & 5.76 & $\mathbf{P}<0.01$ \\
\hline 学 & $30.3 "$ & 50 & $b=0.843$ & 5.62 & $\mathbf{P}<0.01$ \\
\hline 高 & $109.6 \mathrm{~kg}$ & 30 & $b=0.709$ & 5.86 & $\mathbf{P}<0.01$ \\
\hline 校 & $30.3 "$ & 30 & $b==0.636$ & 5.68 & $\mathbf{p}<0.01$ \\
\hline
\end{tabular}

信 5 壮事量と下眼長の相関

\begin{tabular}{|c|c|c|c|}
\hline 等価筫量 & 大学 $(n=50)$ & 高 & 校 $(\mathrm{n}=30)$ \\
\hline $109.6 \mathrm{~kg}$ & $\begin{array}{r}r=-0.0314 \\
(t=0.55)\end{array}$ & & $\begin{array}{r}r=-0.029 \\
(t=0.20)\end{array}$ \\
\hline 30.3 & $\begin{array}{l}r=0.0305 \\
(t=1.69)\end{array}$ & & $\begin{array}{r}r=-0.053 \\
(t=0.35)\end{array}$ \\
\hline
\end{tabular}

表 6 仕事量と筋力の偏相関（下眼長消去）

\begin{tabular}{|c|c|c|c|c|}
\hline 等価筫 & 大 & 学 & 高 & 校 \\
\hline $\begin{array}{c}109.6 \mathrm{~kg} \\
30.3 "\end{array}$ & $\begin{array}{l}r_{12 \cdot 3}=c \\
r_{12 \cdot 3}=C\end{array}$ & $\begin{array}{l}\mathrm{df}=47) \\
\mathrm{df}=47)\end{array}$ & $\begin{array}{l}\mathbf{r}_{12 \cdot 3}=0 \\
\mathbf{r}_{12 \cdot 3}=0\end{array}$ & $\begin{array}{l}\mathrm{df}=27) \\
\mathrm{df}=27)\end{array}$ \\
\hline
\end{tabular}


議の対象となるものに下眼長によつて条件差 がある。すなわち膝関節を伸展するときの角 速度が等しい場合です，下腿の長い者程足頸 部に於てより大きい速度を得る事が出来る。 そこで先ず下腿長と仕事量との相関を調べる と表 5 となつて，その相関はいずれる有意で ない $(\mathrm{P}>0.10)$. 更に下腿長による 条件差を なくする為に，下腿長を消去したときの仕事 量と筋力の偏相関を求めてみると，表 6 とな りいずれる1\%水準で有意である。

以上は男子高校生 及び大学生の結果である が，同様に陸上競技選手の結果について述べ れば次の様である。この被検者群については 4 種の負荷（質量）で腕屈曲及び脚伸展によ る場合を測定した。率引距離は腕屈曲の場合 $25 \mathrm{~cm}$ ，脚伸溒では $40 \mathrm{~cm}$ と規定したもので ある。尚1962年の資料は，動輪を固定した状 態で力一杯辈かせ，然に動輪の制動を解く といら力法9によつたもので，その後の資料 とその絶対值を比䡜することには無理がある。

表 7 出事量と筋力の相関及び仕事の筋力 に対する回帰（脚伸展）

（1962年）

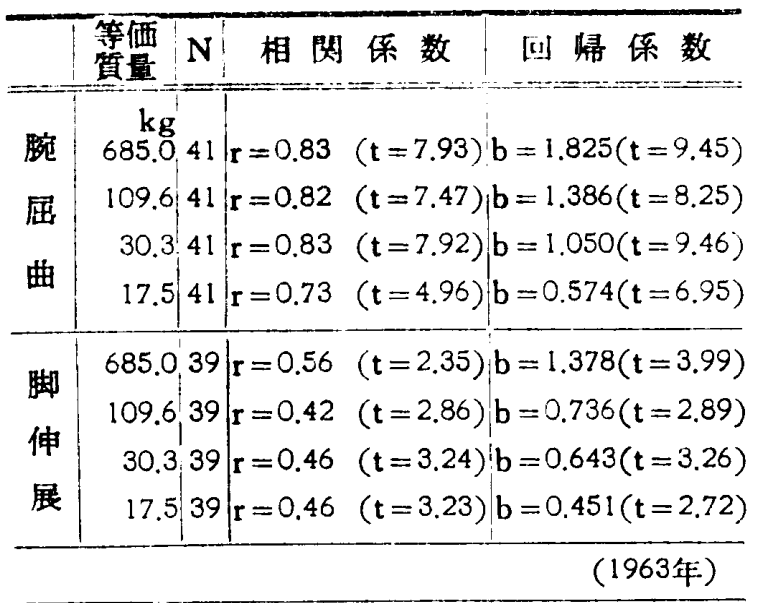

\begin{tabular}{|c|c|c|c|c|}
\hline & 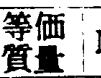 & & 相関係数と $\mathrm{t}$ 値 & 回帰係数と $\mathrm{t}$ 值 \\
\hline 脚 & $\begin{array}{r}\mathbf{k g} \\
685.0\end{array}$ & & $r=0.781(t=5.52)$ & $\mathrm{b}=1.577(\mathrm{t}=7.20)$ \\
\hline 伸 & 109.6 & 34 & $r=0.729(t=4.51)$ & $b=1.083(t=5.98)$ \\
\hline & 30.3 & 34 & $r=0.791(t=5.79)$ & $b=0.674(t=6.88)$ \\
\hline 展 & 17.5 & 34 & $r=0.774(t=4.78)$ & $b=0.668(t=4.70)$ \\
\hline
\end{tabular}

各負荷のもとでの筋力と仕事の相関，及び筋 力に対する仕事の回㷌倸数を一括して示せば 表 7 となる。また図 11，12 は，1962 年の結

图 9 筋力に対寸る仕事の回器 （陸上競技選手・腕屈曲）

\section{Regression of Strength w Work \\ -arm flexion-}

(1) EqM685.0 kg (2) Eq.M.1096 kg (3) EqM. $30.3 \mathrm{~kg}$

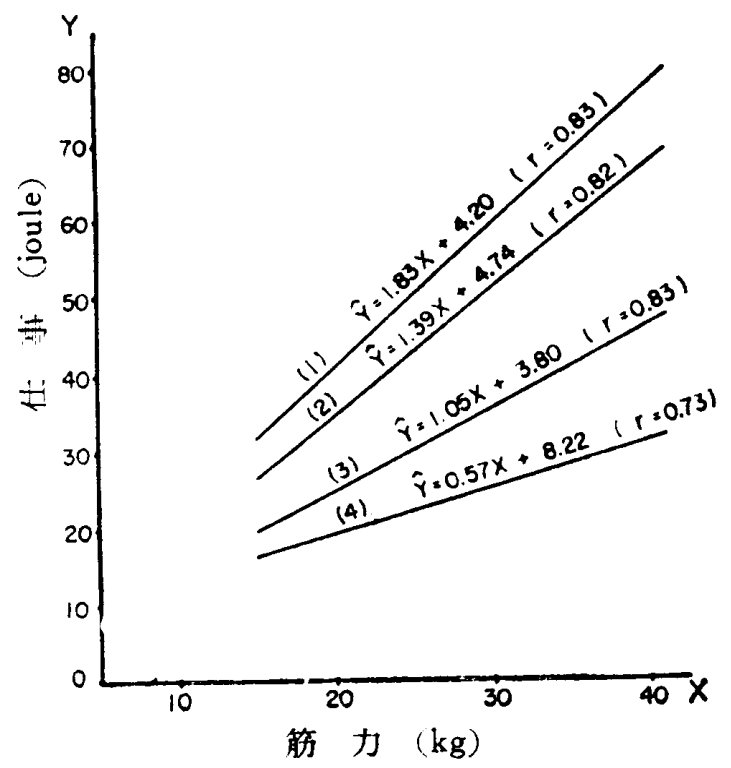

图 10 筇力に対する仕事の回帰 （陸上競技選手・脚伸展）

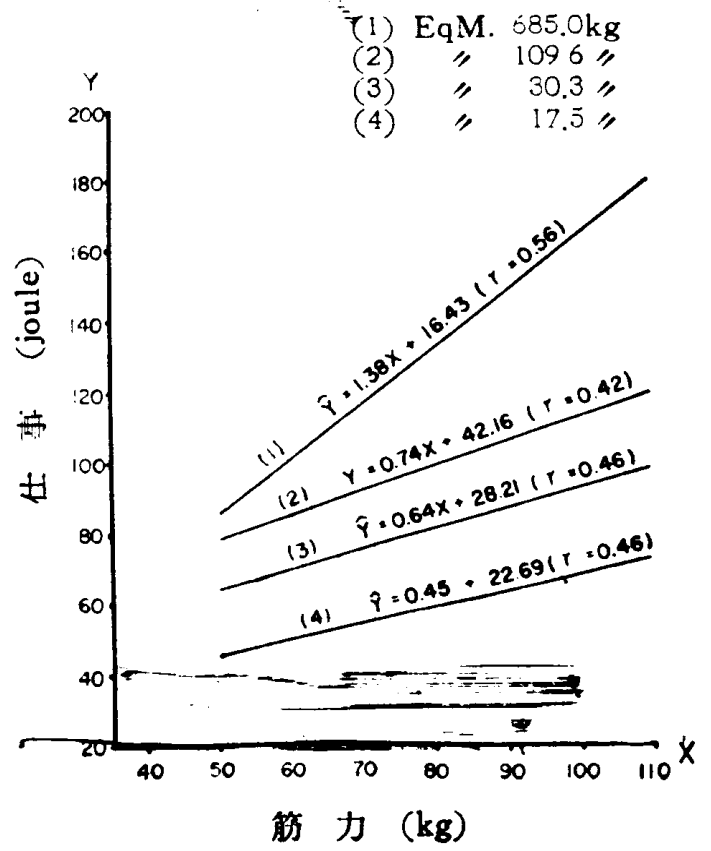




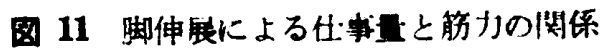
(陸上競技蛋手 1903)

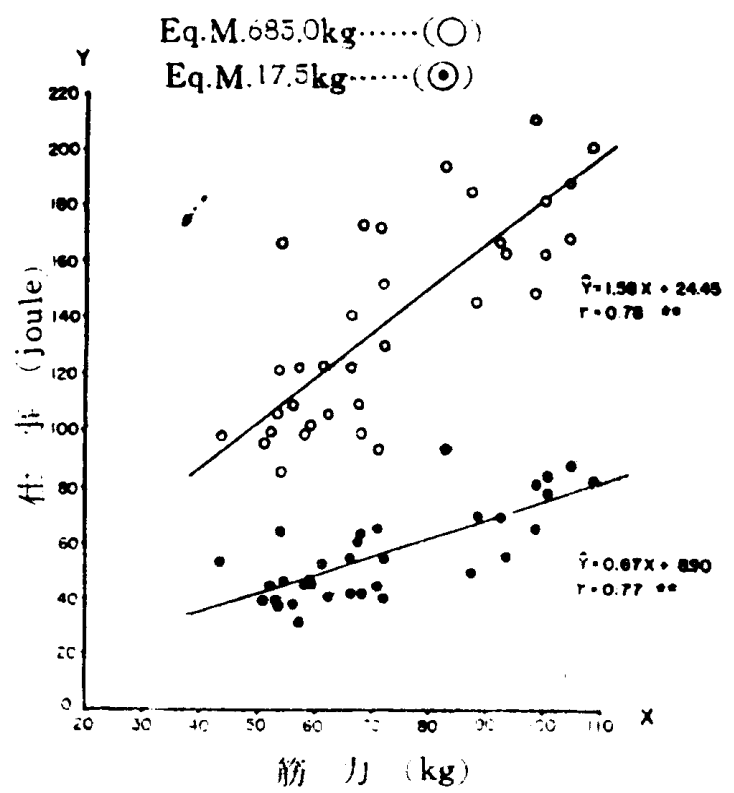

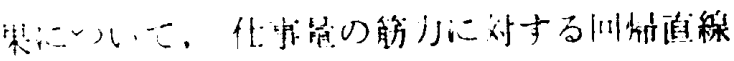

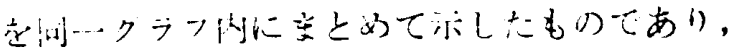

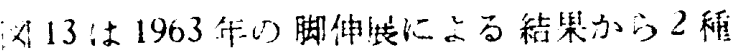

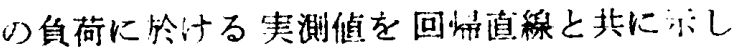
たものである。以上陸」䫓技選手の劫命につ 、ても前述の高校及灭大学生に於けると问㥞 に，仕事量は筋切の大きさによのて左不され ると言5事が出来る。尚も5-.つ, 仕事最の

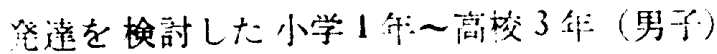

图 12 能力と仕:打统注

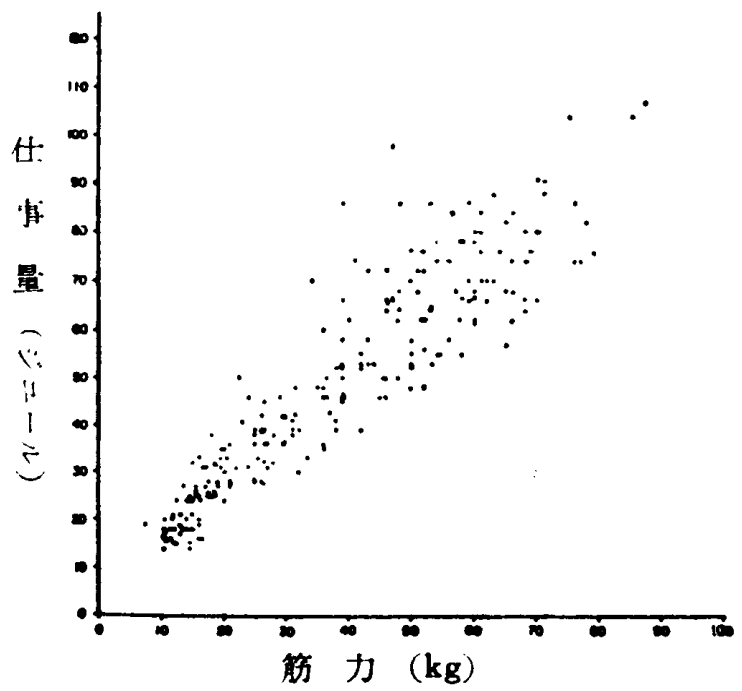

の瓷料から，化事量を筋力との関倸でフロツ トすれば㘠14の様になる。即放仕事量沈か りの幅をもちながらも，㳙少との関係に於て 直楾的に笔逵する事が知られる。しかしこれ をそのまま飰力と仕事の関係とすることは出 来ないななぜらこの中には諸々の形熙的機 能的発達が含まれているからであり，従つて 見かけの相闺と害らべきである．そこで同一 学年内での仕事量と筋力の関係如何といら考 吕片をと门，学年差を消去する偏相関を求め ることとし，random sampling による抽出標 本についてて偏相成係数を求めた結果 $\mathrm{r}_{12.3}=$ $0.594(\mathrm{df}=57)$ となり，これは1\%水準で有 空であつた。期方，各学等内に限つても，仕

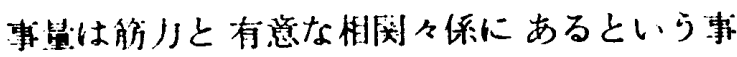
カ治来る。

Henry, F.M.8) らな能力と運動速度（move-

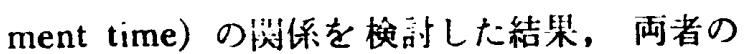
間に有意な相成が沈かつたと報告している。

しかし Chui, E.1) らはウエイト・トレーニン クの結果，筋力の堌加と共に各種のハワー成 結が底くなつたとし，中西ら 12）す问様にウェ イト・トレーニングの結果運動速度が増加した と郝告した。本研究に於ける最小の負荷（等 価質量 $17.5 \mathrm{~kg}$ ）では平均鱼引速度的 $140 \mathrm{~cm}$ /sec（脚伸展）で亟めて速いにも抱わら立， 筋力との間に有意な相関が諮められた。

4. 筇パワー能力の特性

仕事量が筋才との間で密接な関俰にある事 は既に統計的に明らかにした。しかしながら， 実測值を plot した図からす知られるように， 仕事量は肪力の大きさによつて全く一義的に 決められるものではなく，问一肪力の者でも 仕事量は個人によつて珙る。即ち，算力相底 の仕事をなし得る者，またそうでない者があ る。この様に同一筋力に対する仕事量の散布 する幅を矿すのに好都合な指謤として，回必 からの紫售偏差がある。前述の冬被検者群に ついてその俻を算出し，一括して亦したもの が表 8 である． 即ち, 負荷小なる程その值は 


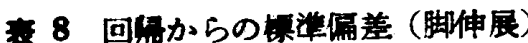

\begin{tabular}{|c|c|c|c|c|}
\hline 等価筫至 & $\begin{array}{l}\text { 大 } \\
(\mathrm{n}=50)\end{array}$ & $\begin{array}{l}\text { 高 } \\
(\mathrm{n}=30)\end{array}$ & $\begin{array}{c}\text { 陸上逜手 } \\
(\mathrm{n}=39) \\
(1962 \text { 年 })\end{array}$ & $\begin{array}{c}\text { 陸上零手 } \\
(\mathrm{n}=34) \\
(1963 \text { 年 }) \\
\end{array}$ \\
\hline $685.0 \mathrm{~kg}$ & - & -1 & 25.1 & 22.8 \\
\hline $109.6 "$ & 8.69 & 7.48 & 25.2 & 20.6 \\
\hline $30.3 \%$ & 8.21 & 6.96 & 19.4 & 10.5 \\
\hline $17.5 n$ & - & 一 & 16.4 & 10.0 \\
\hline (竝) & $30 \mathrm{~cm}$ & ह引। & $40 \mathrm{~cm}$ & 重引 \\
\hline
\end{tabular}

小さく，上り回䭪直楾に添つて仕事量の値が 散布している事がかかる。特に $40 \mathrm{~cm}$ 桬引で 行つた陸上競技運手に於ける值は大きくっこの 施力に対する仕事量の变動の幅を無現して,能 うと仕事量の関倸を論ずる事は出来ない。で は何故に䋛力相応の仕事がなし得る者，なし 栫ない者があるのであららか。この問題につ いて以下に述べ様な2\%の実験により若干 の検討を試みた。

その1ッは筋力のはは等しい被検者につい て，脚伸展による仕事量を筋電四及び張力四 と共に検討したるのである。図15に示した2 被検者の脚伸展筋力は, Sub. T.A. が $68.0 \mathrm{~kg}$, Sub. M.M. が $70.0 \mathrm{~kg}$ である. 筋電図は大眼 直筋の 皮店表面から尊出したものであり， Force curve は栾引ワイヤーの張力変化（張 力四）を記錄したるのでむる。両被検者は管 力がはほ等しいにす抱らず，発揮されている 力は Sub. T.A. の方がいずれの負荷の場合 むより大である。また筋電図の patternを 見ると，運動開始直後に Sub. T.A. ではより 高い電位の筋放軍が現われており，これと対 応して張力の発生る Sub. T.A.に於てより鋭 く，特に負荷小なる场合鋭い揳形を呈してい る。張力図の下段に記録された動㭘の角速度 から两被㭘者の仕事量を算出してみれば表 9 となる. 即ち Sub. M.M. は Sub. T.A. の䄪 70〜80\%の仕事しかなし得ていない，動棆か ら得られる負荷は识性賽田に相当するるので
目 13

Sub T.A.

Sub. M.M.

EMG

Force

m. I

Revol.

time

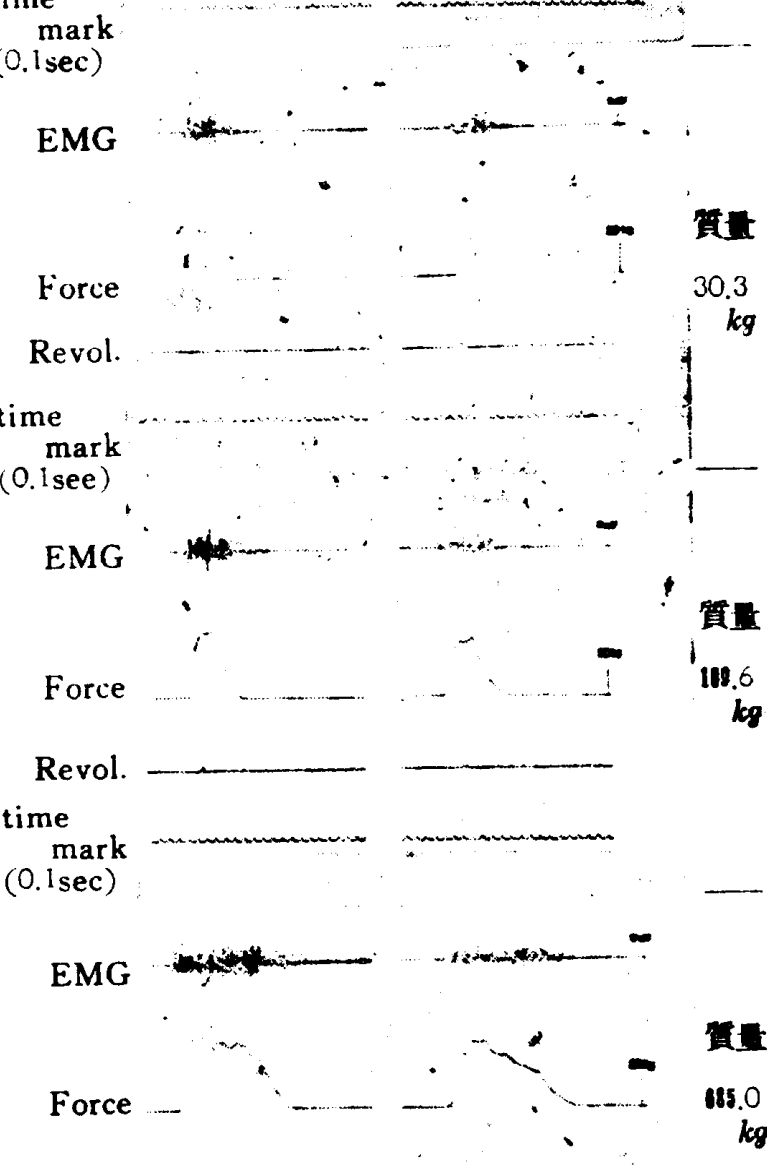

Revol.

time

(0.1sec)

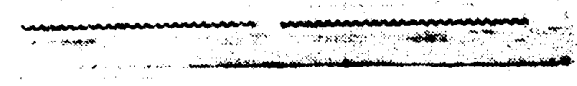

\begin{tabular}{|c|c|c|c|c|c|}
\hline $\begin{array}{l}\text { EQ.MASS } \\
\text { SUB }\end{array}$ & $17.5 \mathrm{~kg}$ & $30.3 \mathbf{k g}$ & $\begin{array}{r}109.6 \\
\mathbf{k g} \\
\end{array}$ & $\begin{array}{r}685.0 \\
\mathbf{k g} \\
\end{array}$ & 第力 \\
\hline T. A. & 63.9 & 84.3 & 104.4 & 132.5 & 68 \\
\hline M. M. & & 58.1 & 73.7 & 119.2 & 70 \\
\hline
\end{tabular}

(単位：Joule) 
あつて，加离られた力に比例した加速度を得 て，容赦なく運動を続けるのであつて、より 速い運動によつて加速度を扣兄る事が出来な ければ，力は使用されずに終つてしまう訳で ある.この事柄を考える時，Sub. M.M. が特 に小さな慣性質量に対して充分に力を発揮し 得ていない事と，仕事量の少ない事は，彼が Sub. T.A. に比べて運動速度に劣るのであろ うと考察される。

他の一ツの実験は腕屈曲によるもので，同 一被険者に all-out 作業を課し，その影嘅が 筇打，仕事量，筋電図にどの程度，どの様な 形で現われかるをみようとしたものである。

即伤作業能力の低下した状態と一般に定義さ
れる披労状俥に於て,仕事量の减少が単に筋力 の減少だけで片づけられるかどらかといら事 である. all-out 作業は腕エルゴメーターによ り最大筋力の $1 / 3$ の負荷, 1 秒 1 回のテンポ で腕屈曲を反復し，屈曲不能になるまで行わ せた。困16は 2 人の被検者に夫々別の負荷の もとで，all-ont 作業前後に仕事量を測定した 際の筋電図，及び張力図である，因をみるに 特に all-out 直後に於て筋電図の pattern が 变り，両被検者とも all-out 前及び回復 7' 後にみられる様な 集中的な筋放電が消失して いる。この時張力図は钝い立ち上りから低い 山形を呈している。この慎向は先に述べた， 筋力が等しくしかも仕事量に劣る Sub. M.M.

图 14 箭疲学による影

Sub. T. AS. (前 all out (30"啳)

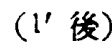

(7' 铬)

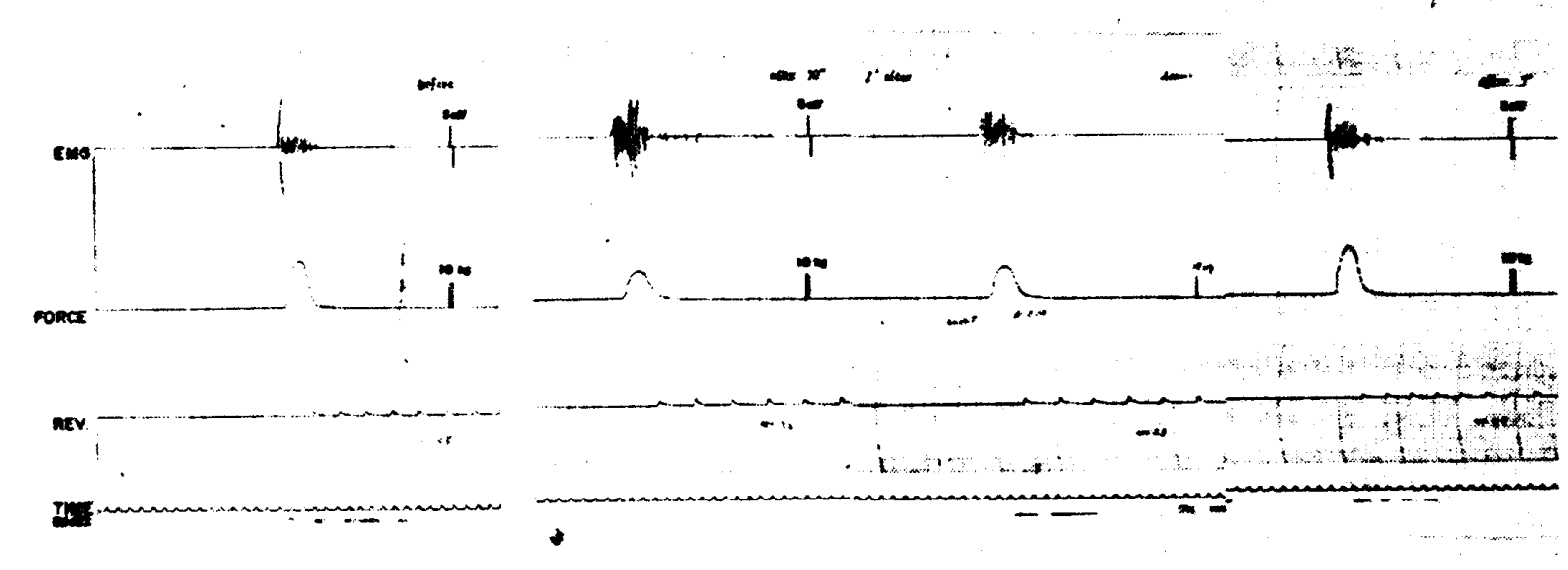

Sub. M.MA.

（前）

$\underset{\Downarrow}{\text { all-out }}$

(30'後)

(1'後)

(7'後)

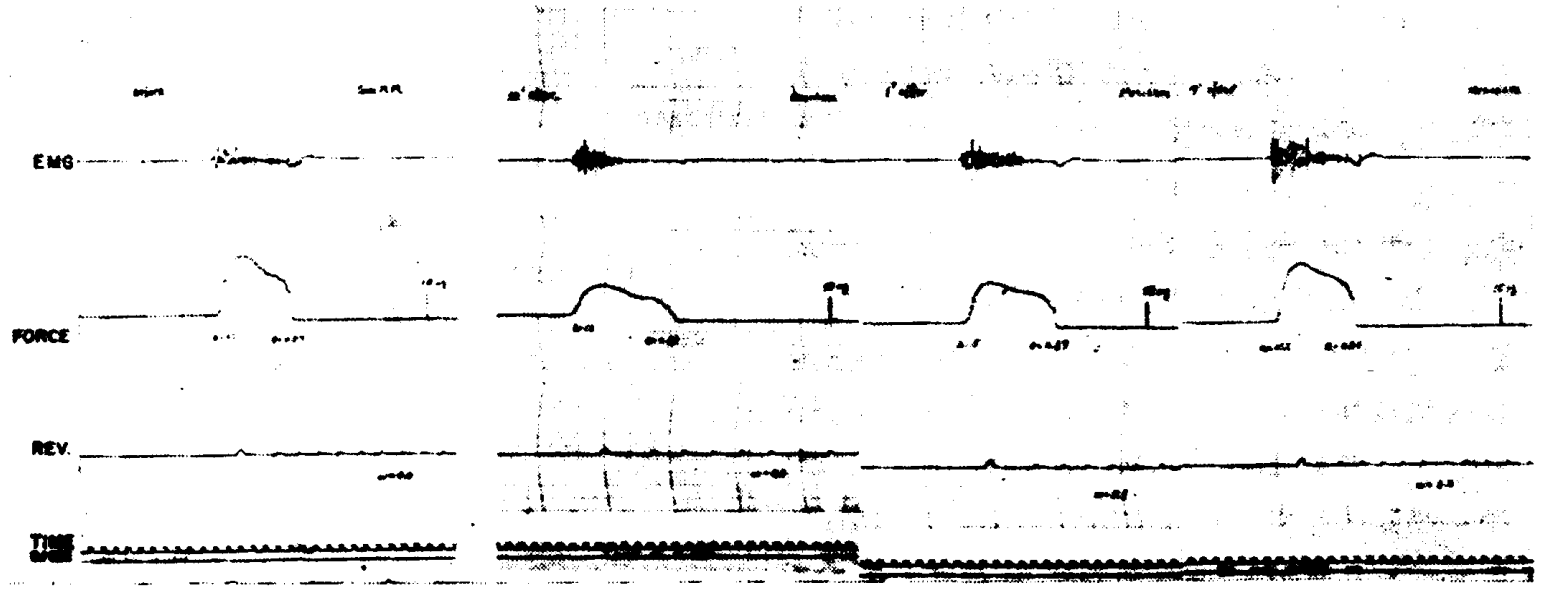


图 15 笳疲労による影

Sub. T.A. (Asami)

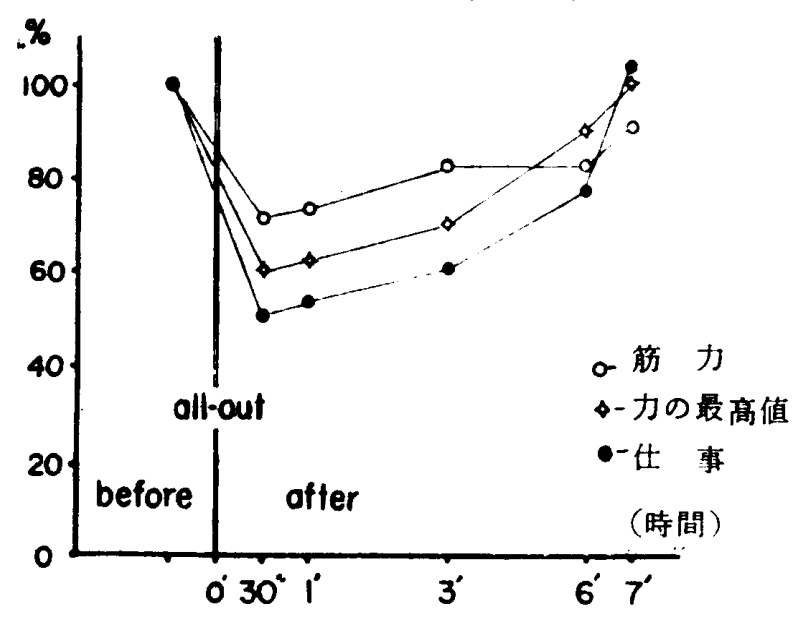

にみられる様相に似ている。しかしこの場合 すぐ運動速度の減少が原因であるとする事は 出来ない，なぜなら筋力る又低下しているか らである。そこで日を改め同一 all-out 作業 を課して筋力の低下する度合を調べた。四 17 は等力，仕事量及び張力図の片の最高值の娍 少与る度合（\%）を，時間を追つて示したも のである（筇力及ご仕事䁆の減少する度合は 他に 3 名の被検者についても同傾问を示すこ そを認めた）。この図から言える事は，静的な 筋力が all-out 直後 $80 \%$ となたのに対し， 慣性動輪に対して発揮し得た力の最高值は all-out 前の 45〜60\%になつている． 即ち， 筋力には尚余裕を残しながら，それが動的に は発揮し得ていないのである．先に示した回 㷌直袙に照合し，笳力の减少に対応する仕事 量を又ても，それは筋力相応以下の値を示し ている、この样に考えて来ると, 疲労による 仕事量の减少した要因は，筋力の低下による と共に，運動速度の减退によるものであると 言ら事が出来よ5。

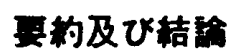

觧的な状態で発揮する筋力（最大筋力）と， 動的に力を哞揮してなし得る仕事量（最大仕 事量）との関係を㭘討した。仕事量は慣性エ

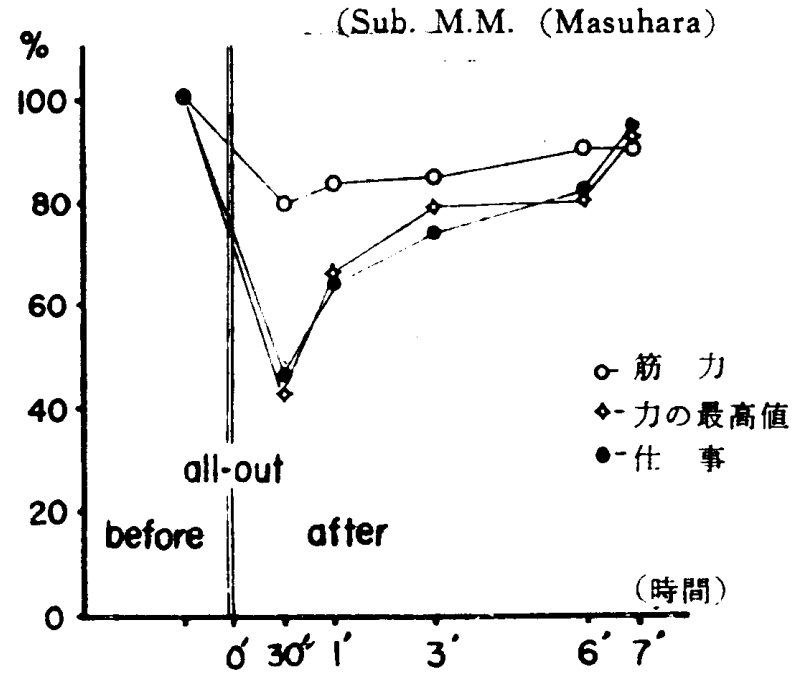

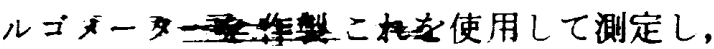

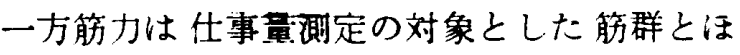
ぼ同一筋群の等尺性収収縮による筋力を， dynamometer によつて测定した。主として 高校，大学，陸上競技選手を被挨者とする 測定結果及び 2 ッの実験結果から次の事を知 つた。即ち，1）慣性質量に対して瞬発的に力 を発揮してなし得る仕事量は，筋力との間に 高い相関関係をもら，大なる仕事をするには 筋力に優れている事が有利な条件となる．2） しかし筇力本充分飞動的婸面で生かす為に は，在以迹動を起し得なければならないが， そこには神経衡撃の集中性如何が関係すると 考えられる。

本研究は猪飼道夫教授の留切なる御指導と東 大体育学研究室諸兄の御助力のもとで行われた あのである．ここに記して深謝の意を表します．

\section{女 献}

1) Chui, E. (1950): Effect of systematic weight training on athletic power. Res. Quart. 21 , (3) p. 188 194.

2) Englehaldt, J.L. (1924): A test of physical efficiency. - f. Educational Psychol. 15, p. $573 \approx 578$.

3) Fenn, W.0. (1935): Muscular force at 
different speed of shortering. J. physiol. 85. p. $277 \sim 297$.

4) Gray, R.K. 他 (1962): A test of leg power. Res. Qnart 33, (1), p.44 50

5) Gray, RK. 他 (1962): A useful modification of vertical power jump. Res. Quart. 33, (2) p.230 235

6) Hill, A.V. (1922): Maximum work and mechenical efficiency of human musecles and their most economical speed. J. physiol 56, p. $19 \sim 41$.

7) Hansen, T.E. \& Lindhard, J. (1923): On the muscular work of human muscles especially the flexors of the elbow. J. physiol. 57. p. $287 \sim 300$

8) Henry, F.M. (1960): Factorial structure of speed and static strength in a lateral arm movement. Res. Quart. 31 (3), p.440
447.

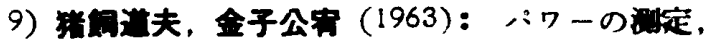
OLYMPIA, 4(2) p.68 75

10) Lupton, H. (1923): The relation between the external work produced and the time ocupied in a simgle muscular contraction.

J. Physio.1 57, p.68 75

11) McCloy, C.H. (1932): Recent studies in the Sargent Jump. Res. Quart. 3(2), p.235 $\sim 242$

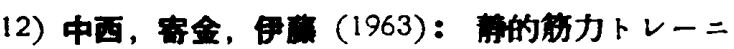

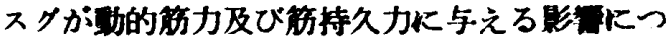
いて, 体有の科学, 13(1) p.10〜17

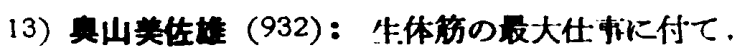
为的科学, $9(5), p .501 \sim 523$

14) Wilkie, D.R. (1950): The relation between force and velocity in human muscle, $J$. physiol, 110, p.249 280. 


\section{A Study on the Human Muscle Power with Inertia Ergometer}

\section{By \\ M. Kaneko ; University of Tokyo}

The relation between the strength and the power was investigated in the arm flexor and knee extensor muscles respectively. In order to measure the muscle power, a modified Inertia Ergometer and the muscel strength was ordinarily measured with spring dynamometer.

It was found that the muscle power measure in four kinds of loads was significantly related to the strength of individuals, while some individual differences were observed. Based on the electromyograms and the force curves it was revealed that the power ability was determinded by how to concentrate their nerve impulses to the acting muscles in addition to the strength.

Pletysmographic Measurement of the Blood Flow through the Forearm in Muscular Exercise

By

\section{A. Nakamura; University of Tokyo}

The water pletysmograph for the forearm, with electric recording apparatus, including an ergometer, was devised and presented. The collecting pressure applied to the arm was ascertained and the pressure lower than the dyastolic pressure by $5 \sim 10$ $\mathrm{mmHg}$, applied for 5 10 seconds, was found to be adequate to record the blood inflow to the tissue. By means of this method, it was demonstrated that the forearm blood flow was increased after exercise of maximum efforts exerted every two seconds, and the increase of blood flow was related to the number of maximum contractions, but it seemed to reach a plateau after certain contractions. Remarkable increase of blood flow was also found after exercise with the load of one-third of maximum strength to exhaustion. Among subjects, a large difference of blood fflow was found after both kinds of exercise. 